\title{
Treatment of Supraclinoid Internal Carotid Artery Iatrogenic Pseudoaneurym with Extracranial-to- Intracranial Bypass and Trapping: Demonstration of Technique with Video Presentation
}

\author{
Supraklinoid Internal Karotid Arter Psödoanevrizmasının Kafa Dışı- \\ Kafa İci Bypass ve Damarsal Tuzaklama ile Tedavisi: Tekniğin Video ile \\ Gösterimi
}

Ulas CIKLA ${ }^{1}$, Yiping LI ${ }^{1}$, Silvia HERNÁNDEZ-DURÁN², Abdulbaki KOZAN', Mustafa K. BASKAYA ${ }^{1}$

${ }^{1}$ University of Wisconsin Medical School, Department of Neurological Surgery, Madison, Wisconsin, USA

${ }^{2}$ University of Costa Rica, School of Medicine, Neuroanatomy Section, Ciudad Universitaria Rodrigo Facio, Apdo. 1232-1007, San José, Costa Rica

Corresponding Author: Mustafa K. BASKAYA / E-mail: m.baskaya@neurosurgery.wisc.edu

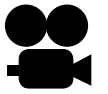

To watch the surgical videoclip, please visit http://turkishneurosurgery.org.tr/images/13039_video.mp4

\begin{abstract}
Intracranial pseudoaneurysms (IP) represent about $1 \%$ of all patients presenting with an intracranial aneurysm. In true intracranial aneurysms, the intima, internal elastic lamina, and media are disrupted, but the adventitia is intact. In pseudoaneurysms, there is disruption of all three layers of the arterial wall, thus resulting in higher rates of re-hemorrhage and thrombus formation. Patients with IP commonly present with subarachnoid hemorrhage or thromboembolic complications. Until now, no specific guidelines have been established for the ideal treatment of pseudoaneurysms. Although IP have higher rates of morbidity and mortality compared to true intracranial aneurysms, surgical treatment can prevent catastrophic hemorrhagic and thrombotic complications. Despite recent advances in endovascular techniques that allow safe approaches to complicated intracranial vascular pathologies, vascular trapping and bypass remains the definitive and safe treatment for IP. Based on our experience and related literature, we consider the latter treatment in experienced hands as an effective and decisive treatment modality to prevent the devastating complications of IP. In this article, we discuss the surgical management of iatrogenic intracranial internal carotid artery pseudoaneurysms by trapping, and extracranial-intracranial bypass through a case illustration in which the technique is demonstrated via a video presentation.
\end{abstract}

KEYWORDS: Bypass, Trapping, Pseudoaneurysm, Surgery

öz

Kafa içi psödoanevrizma (KiP) lar tüm kafa içi anevrizmaların \%1'ini oluşturur. Gerçek kafa içi anevrizmalarda intima, iç ve orta elastik laminalarda hasar görülürken, adventisya tabakası sağlamdır. Psödoanevrizmalarda ise arter duvarının tüm tabakalarında hasar olması sebebiyle yeniden kanama ve trombüs oranı yüksektir. KiP'li hastalar subaraknoid kanama veya tromboembolik komplikasyonlarla prezente olurlar. Şu ana kadar psödoanevrizmaların tedavisi ile ilgili fikir birliğine varılamamıştır. Gerçek kafa içi anevrizmalarla karşılaştııldığında yüksek morbidite ve mortalite oranları olmasına karşın, KIP'li hastalarda cerrahi tedavi katastrofik kanama ve trombotik komplikasyonları önleyebilir. Son dönemdeki komplike kafa içi damarsal patolojilere yönelik endovasküler tedavilerdeki gelişmelere rağmen, damarsal tuzaklama ve bypass hala güvenli ve kalıı bir tedavi yöntemidir. Klinik tecrübemiz ve literatür ışığında damarsal tuzaklama ve bypass'ın KiP'e bağlı yıkıcı komplikasyonların önlenmesinde etkin ve kalıcı sonuçlar verdiği görülmektedir. Çalışmamızda internal karotid arterde iyatrojenik KiP'in cerrahi yönetimi, kafa dışı-kafa içi bypass ve damarsal tuzaklama yapılan bir hastanın video sunumu eşliğinde tartışılmıştır.

ANAHTAR SÖZCÜKLER: Bypass, Tuzaklama, Psödoanevrizma, Cerrahi 


\section{INTRODUCTION}

latrogenic internal carotid artery (ICA) pseudoaneurysms are a very rare complication of neurosurgical, otolaryngologic and maxillofacial procedures. Due to their greater tendency to rupture, pseudoaneurysms are associated with higher morbidity and mortality when compared to true intracranial aneurysms (7). The former is the product of arterial damage resulting in injury to the media, and/or adventitia of the vessel wall. If the adventitia is disrupted, a hematoma may form outside the arterial wall, but it continues to communicate with the injured vessel, thus predisposing it to re-bleeding. Loss of integrity between the media and the adventitia also creates a false lumen. As blood accumulates in this false lumen, thrombosis in the subadventitial plane can occur, with subsequent thromboembolism or arterial rupture being major risks (5).

To date, no specific guidelines have been established for the ideal treatment of pseudoaneurysms. Based on our experience and related literature, we consider that trapping aneurysm with vascular bypass in experienced hands is an effective and a definite treatment modality to prevent the hemorrhagic and thrombotic complications of pseudoaneurysms $(1,6,7,8)$. In this article, we discuss the surgical management of intracranial iatrogenic ICA pseudoaneurysms by trapping and extracranial-intracranial (EC-IC) bypass along with a case illustration in which the technique is demonstrated with video presentation.

\section{CASE ILLUSTRATION WITH VIDEO PRESENTATION}

We present the case of a 68-year-old male who had a history of a tuberculum sellae meningioma, operated on twice at different outside hospitals. The first surgery was performed 20 years ago, and post-operatively the patient received radiotherapy. The patient underwent a second operation for tumor recurrence at a different outside facility (Figure $1 \mathrm{~A}-\mathrm{C})$. During the surgery, brisk arterial bleeding coming from the ICA was observed. The bleeding was controlled with packing intra-operatively. Post-operative angiogram revealed a pseudoaneurysm in the supraclinoid segment of the ICA (Figure 2). The patient was transferred to our hospital for further management. On examination, the patient was intubated and was following commands in all extremities. He had diabetes insipidus. MRI done at our institution (Figure 3) showed infarcts correlating with left A1 occlusion as demonstrated in repeat angiogram. The repeat angiogram showed an enlarging pseudoaneurysm of the left supraclinoid ICA with superior projection (Figure 4A, B). The decision was made to treat this pseudoaneurysm with EC-IC bypass and trapping.

Prior to the craniotomy, the radial artery (RA) was harvested and the neck was dissected to expose the common carotid (CCA), ICA and external carotid (ECA) arteries. This was performed to obtain proximal control and to isolate the ECA as a donor vessel. The patient's previous frontotemporal craniotomy was re-opened. Scarring and arachnoid

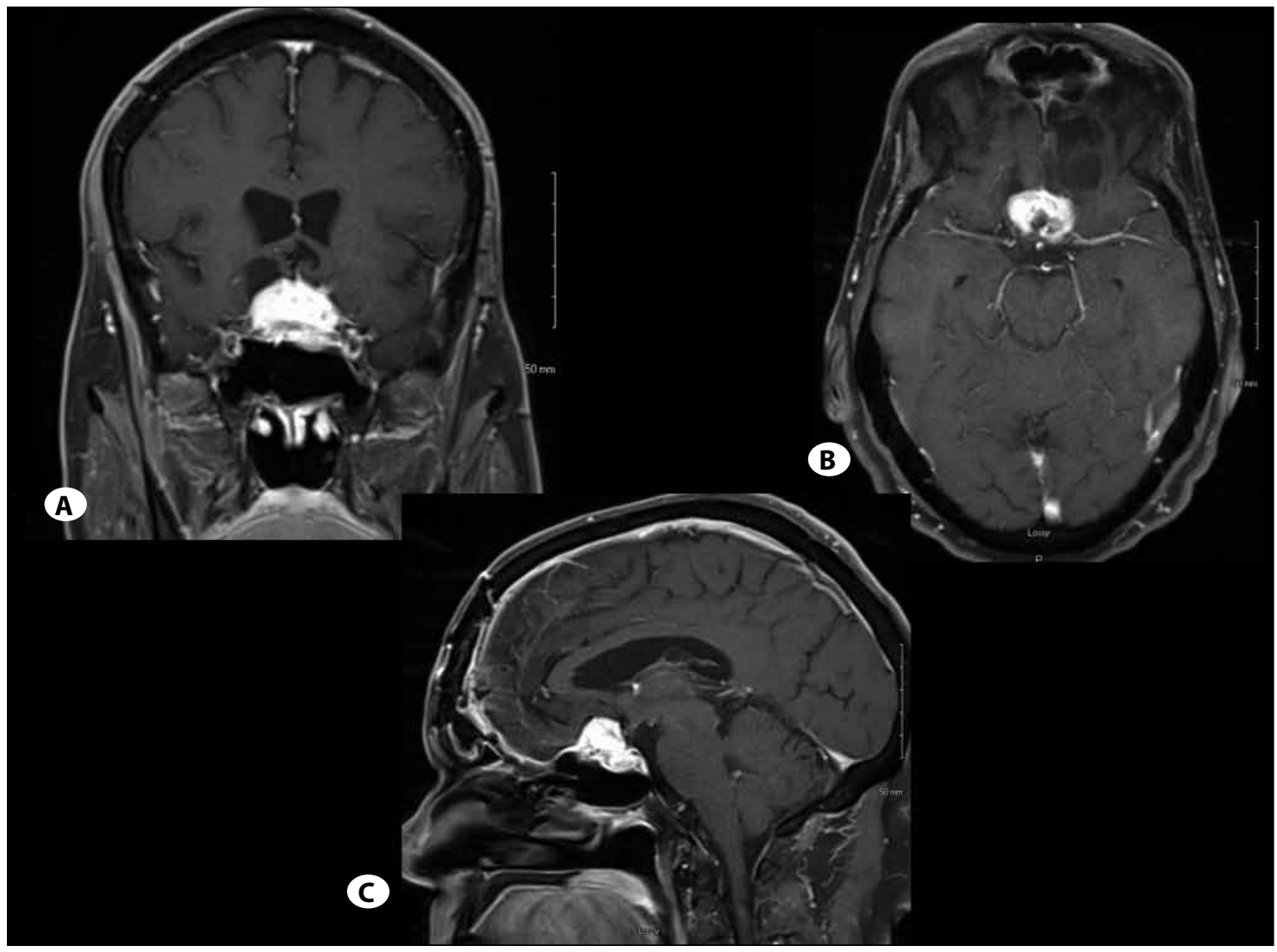

Figure 1:

A) Coronal,

B) axial,

C) sagittal T1 postcontrast MRIs show a recurrent/ residual tuberculum sella meningioma. 
adhesions were noted during dural opening. The Sylvian fissure was dissected to expose the middle cerebral artery (MCA) bifurcation and M2 branches. The temporal M2 branch had good caliber and appeared to be a good recipient artery for distal bypass. The temporal M2 was then isolated and prepared for the bypass. The RA graft was prepared on each end by performing an adventisectomy and fish-mouthed. The RA was then tunneled over the zygoma and down to the neck incision with a pediatric chest tube.

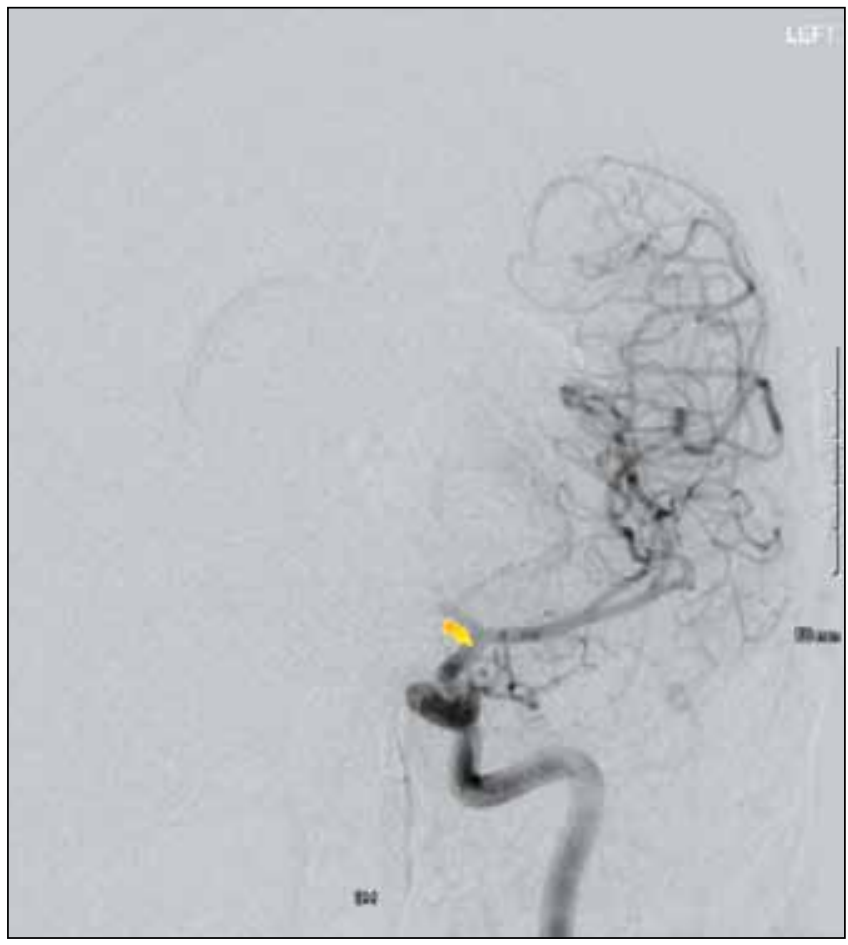

Figure 2: Initial angiogram performed at the outside facility shows a pseudoaneurysm in the supraclinoid segment of internal carotid artery (ICA) and occlusion of the left proximal anterior cerebral artery (ACA).

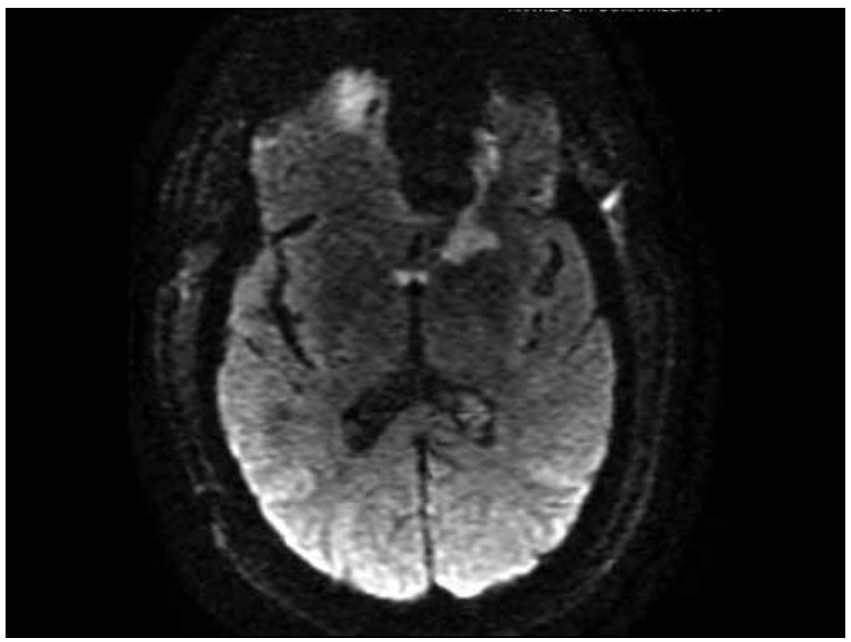

Figure 3: Axial diffusion-weighted MRI shows multiple infarcts consistent with proximal ACA occlusion.
After placing the patient in burst suppression, temporary clips were placed proximally and distally on the temporal M2 segment. A small arteriotomy was made on the side of the vessel for anastomosis. Toe and heel stitches were placed from the RA to the side of the $M 2$ branch and interrupted stitches were placed using a 10-0 nylon suture. Upon completion of the anastomosis, the temporary clips were removed from the $\mathrm{M} 2$ and a temporary clip was left on the RA graft. Indocyanine
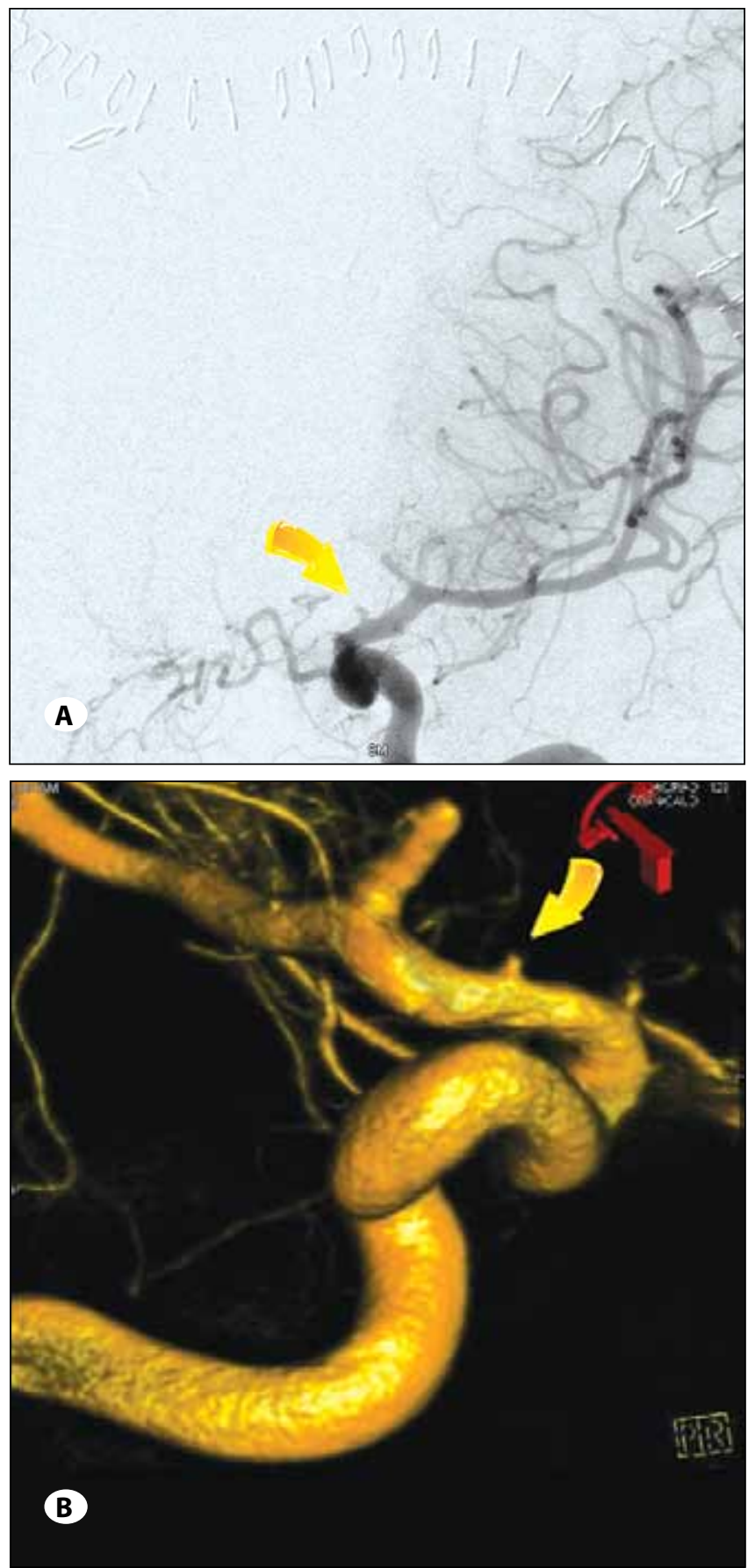

Figure 4: A) Preoperative left carotid and B) 3D reconstruction angiograms performed in our hospital confirm slightly enlarging supraclinoidal ICA pseudoaneurysm. 
green video angiography was used to evaluate the patency of the distal bypass graft. At this point, the proximal end of the graft was prepared in a similar manner. The ECA and its branches were dissected and isolated. Next, temporary clips were placed on all of the ECA branches, and proximally and distally on the ECA itself. Doppler ultrasonography was used to detect any blood flow prior to performing the arteriotomy. After the arteriotomy was created on the side of the ECA, the proximal end of the RA graft was sewn again with toe and heel stitches and using interrupted 8-0 nylon stitches. Upon completion of the bypass, the temporary clips were removed, restoring flow through the ECA. Surgicel and Gelfoam were used to stop any bleeding from the anastomosis sides. Doppler ultrasonography was used to assess the patency of the graft both in the head and in the neck. Next the surgery was directed intracranially where the remainder of the proximal Sylvian fissure was carefully dissected. The supraclinoid ICA was dissected, isolated and the pseudoaneurysm under the optic nerve was barely visualized. To avoid disrupting the pseudoaneurysm, further dissection to expose the aneurysm was not performed. A curved aneurysm clip was placed across the ICA, proximal to the origin of the posterior communicating artery. The posterior communicating and anterior choroidal arteries were inspected for patency postclipping. Micro-Doppler ultrasonography was used to confirm flow within the distal ICA and its branches. After obstructing the ICA flow distally, the pseudoaneurysm in the proximal ICA was effectively trapped by placing two suture ligatures on the ICA in the neck. Indocyanine green video angiography and Doppler ultrasonography confirmed effective trapping and excellent flow through the bypass graft. Post-operative angiogram demonstrated good flow through the bypass graft and total obliteration of the trapped ICA segment (Figure 5A, B). The patient had an unremarkable hospital course and made an excellent recovery.

\section{DISCUSSION}

Injury to the ICA resulting in the formation of pseudoaneurysms during surgical procedures is estimated to occur in only $1.1 \%$ of the cases (6). Anatomical anomalies or variations, multiple surgeries, venous sinus thrombosis and prior radiotherapy significantly increase the risk of pseudoaneurysm formation (4). This complication can be potentially fatal immediately or in a delayed fashion from rebleeding or embolic stroke (5) Surgical procedures associated with pseudoaneurysm formation include endoscopic transsphenoidal surgery, endoscopic transfacial-transmaxillary surgery, myringotomy, cavernous sinus tumor resections, and intracranial vascular procedures (6). Risk factors for iatrogenic ICA injury resulting in pseudoaneurysm formation include anatomic variations of the temporal and sphenoid bones, tumors invading the cavernous sinus, tumors encasing the ICA, and increased tortuosity of the ICA (3).

In comparison to the extracranial arteries, the intracranial arteries have a thinner media and adventitia, lack an external elastic lamina, and possess a thicker internal elastic lamina with diminished vasa vasorum (5). These characteristics make the intracranial arteries more vulnerable to iatrogenic injury.
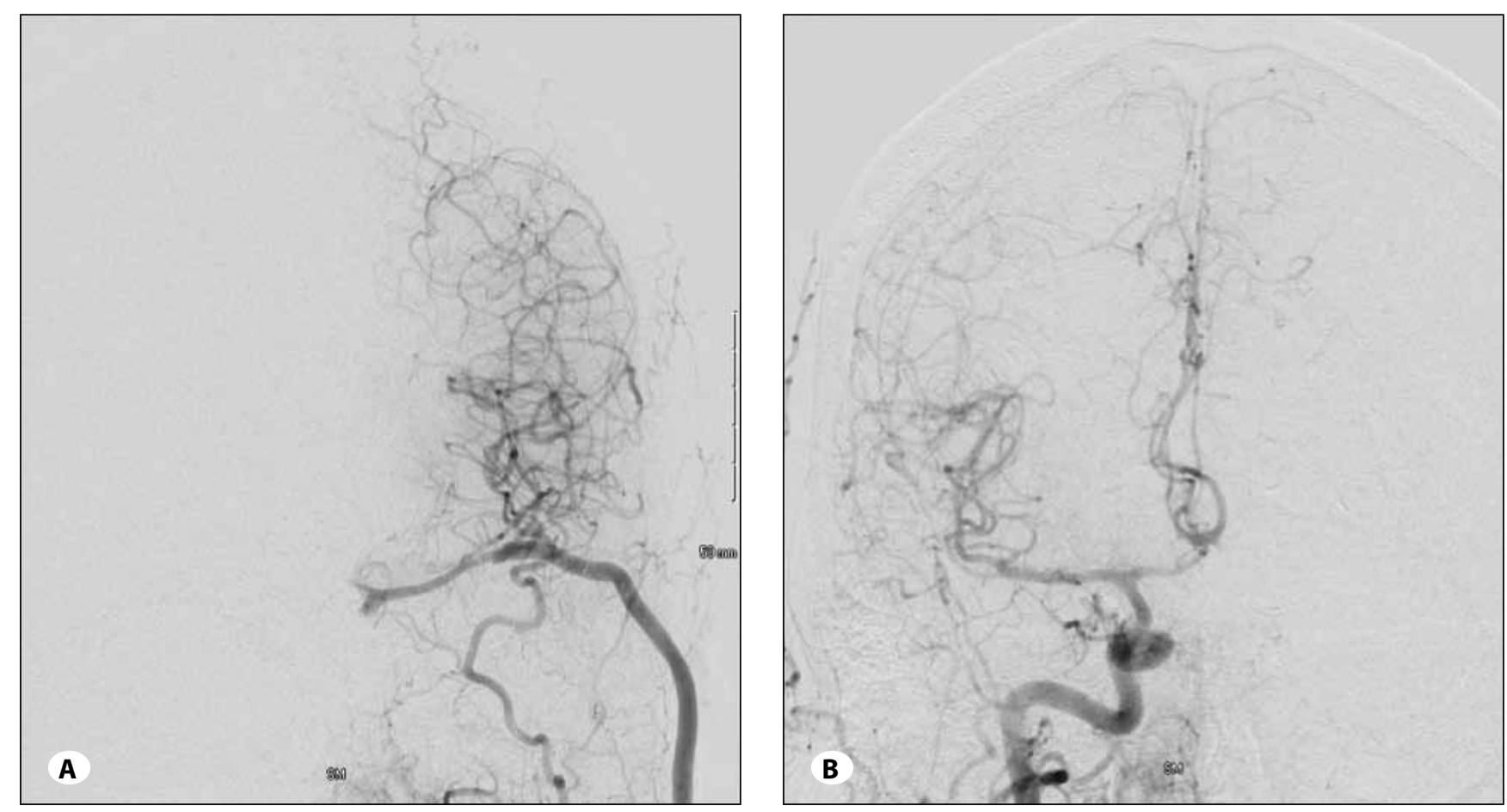

Figure 5: Postoperative $\mathbf{A}$ ) left and $\mathbf{B})$ right carotid angiograms show filling of the MCA branches via the bypass with complete aneurysm trapping on the left side (A) and filling of both ACAs from right A1 on the right side (B). 
Treatment options for ICA pseudoaneurysms include surgical repair or endovascular surgery. Indications for endovascular therapy include (a) clinical failure of medical therapy; (b) impending strokeattributable to significant stenosis/occlusion with poor collateral circulation and reduced parenchymal perfusion on imaging; (c) contraindication to anticoagulation; (d) evidence of symptomatic thromboembolic occlusion of cerebral vessels; (e) contralateral carotid stenosis/occlusion; (f) need for elective occlusion of the contralateral ICA for other disease; (g) need to avoid flow increase through the anterior communicating artery because of an associated aneurysm (2, 5). However, endovascular treatment in the form of stenting is complicated by the need for peri-procedural anticoagulation and dual antiplatelet therapy.

Bypass grafting is currently performed electively for the management of giant intracranial aneurysms, moyamoya disease, and other vasculopathies. On the other hand, bypass grafting was traditionally used for the management of acute stroke in patients needing urgent cerebral revascularization, but most practitioners have stopped this practice because of low success rates (3). Recently, Rangel-Castilla et al. (6) reported on the use of high-flow revascularization bypass surgery for iatrogenic skull base ICA injuries with very favorable results, with a mean follow-up period of 19 months. As their experience shows, open surgery can be a suitable alternative in cases not amenable to endovascular treatment, yielding favorable outcomes. Advantages of surgical revascularization include limited ischemia times, as occlusion is only during the time needed to perform the bypass, and preservation of the afferent and efferent vessels around the pseudoaneurysm.

\section{CONCLUSION}

Intracranial pseudoaneurysms frequently arise secondary to blunt or penetrating injury to the intracranial vasculature. They often occur by iatrogenic arterial injury during surgical procedures. Although intracranial pseudoaneurysms have higher rates of morbidity and mortality when compared to true intracranial aneurysms, surgical treatment can prevent catastrophic hemorrhagic and thrombotic complications. Despite recent advances in endovascular techniques, which allow safe approaches to complicated intracranial vascular pathologies, vascular trapping and bypass grafting is also a definite and safe treatment for intracranial pseudoaneurysms.

\section{REFERENCES}

1. Baskaya MK, Ahmed AS, Ates O, Niemann D: Surgical treatment of blood blister-like aneurysms of the supraclinoid internal carotid artery with extracranial-intracranial bypass and trapping. Neurosurg Focus 24 (2): E13, 2008

2. Biondi A, Katz J, Vallabh J, Segal A, Gobin Y: Progressive symptomatic carotid dissection treated with multiple stents. Stroke 36: E80-E82, 2005

3. Ciceri E, Regna-Gladin C, Erbetta A, Chiapparini L, Nappini S, Savoiardo M, Di Meco F: latrogenic intracranial pseudoaneurysms: neuroradiological and therapeutical considerations, including endovascular options. Neurol Sci 27: 317-322, 2006

4. Kadyrov NA, Friedman JA, Nichols DA, Cohen-Gadol AA, MJ, Piepgras DG: Endovascular treatment of an internal carotid artery pseudoaneurysm following transsphenoidal surgery. Case report. J Neurosurg 96:624-627, 2002

5. Larson PS, Reisner A, Morassutti DJ, Bassam A, Harpring JE: Traumatic intracranial aneurysms. Neurosurg Focus 8: 1-6, 2000

6. Rangel-Castilla L, McDougall CG, Spetzler RF, Nakaji P: Urgent cerebral revascularization bypass surgery for iatrogenic skull base ICA injury. Neurosurgery 10 Suppl 4:640-647; discussion 647-648, 2014

7. Raymond J, Hardy J, Czepko R, Roy D: Arterial injuries in transsphenoidal surgery for pituitary adenoma; The role of angiography and endovascular treatment: AJNR Am J Neuroradiol 18:655-665, 1997

8. Saito K, Baskaya MK, Shibuya M, Suzuki Y, Sugita K: False traumatic aneurysm of the dorsal wall of the supraclinoid internal carotid artery--case report. Neurol Med Chir 35: 886891,1995 